\title{
Characteristics of discharge at Rose and Gellért Hills, Budapest, Hungary
}

\author{
Anita Erôss, Judit Mádl-Szőnyi \\ Department of Physical and Applied Geology \\ Eötvös Loránd University, Budapest
}

\author{
Anita É. Csoma \\ Carbonate Research Team (EPT-RHI) \\ Shell International EEP, Rijswijk, The Netherlands
}

\begin{abstract}
This study focuses on the discharge characteristics of the Buda Thermal Karst (Budapest, Hungary) found at the Rose and Gellért Hills. The Buda Thermal Karst is a recently active hydrothermal karst system in the heart of Budapest. Studying this unique hydrogeologic system is thus a challenge because of the human impact effects. The research approach is based on the concept of hydrological system analysis (Engelen and Kloosterman 1996), which means that the flow system geometry and recharge-discharge features must correlate when the influence of man on the flow regimes of an area is negligible. Therefore the flow system geometry could be deduced from the evaluation of manifestations of flowing groundwater. To achieve this archival hydrogeologic data and recent observations were used. Based on the localization of springs, collections of archival temperature and chemical data, as well as recent observations, conceptual models were established for the discharge in the Rose Hill and Gellért Hill areas. The observations indicate different discharge characteristics for the two study areas.
\end{abstract}

Key words: discharge features, thermal spring, tectonic element, precipitates, Buda Thermal Karst

\section{Introduction and objectives}

The capital of Hungary, Budapest, has a particular hydrogeologic setting. The recently active Buda Thermal Karst system can be studied through thermal springs and underwater caves. According to Dublyansky (2000) this area may serve as a perfect "test site" for hydrothermal karst studies. Nevertheless knowledge of how the Buda Thermal Karst System functions is far from complete.

Addresses: A. Erôss, J. Mádl-Szőnyi: H-1117 Budapest, Pázmány P. stny. 1/C, Hungary

A. É. Csoma: Kessler Park 1 At205R Rijswijk, 2288 GS The Netherlands e-mail: anita.eross@gmail.com

Received: September 1, 2008; accepted: December 14, 2008 
Karst development has long been attributed to the action of groundwater. The effects of flow systems and their dynamics, distribution, and patterns on the evolution, depth and geometry of a karst system, as well as on karst water chemistry, have been also long recognized and studied (e.g. Bedinger 1967; La Fleur 1984; Back et al. 1992). Accordingly, karst, caves and precipitates can be considered as a geologic manifestation of flowing groundwater (Tóth 1984, 1999) and, on the other hand, karst springs can be interpreted as discharge features in a specific hydrogeologic environment (Tóth 1971).

The discharge of the Buda Thermal Karst system is confined to a narrow, tectonically controlled area. It is found from Tata to Budapest along the west bank of the river Danube, and also in the riverbed. In the heart of Budapest, more than 120 springs with widely different temperatures and chemical compositions were identified (Alföldi et al. 1968). This particular discharge feature is accompanied by strong convective heat flow and increased $\left(75-100{ }^{\circ} \mathrm{Ckm}^{-1}\right)$ geothermal gradient (Lorberer 2002). In the area of Rose Hill lukewarm, warm, and hot springs arise next to each other. To the south, at Gellért Hill, mainly hot springs occur (Alföldi et al. 1968).

The natural springs have been substituted by wells in the last eighty years for sanitary reasons. The water withdrawal of the operating pumping wells influences the discharge of the system. In addition, the original discharge manifestations (e.g. springs, seepages, exhalations, precipitates) are difficult to recognize owing to the obscuring impact of the urbanization of different periods of history. Consequently, the current hydrogeologic system has an artificially influenced groundwater discharge. For the understanding of different flow systems that are conveying water to this concentrated discharge area it is crucial to know the locations, temperatures, and chemical compositions of the original springs.

The main objective of this paper is to identify, document and evaluate the primary discharge features, for instance location of the upwelling, temperature, chemical composition of the thermal springs in the surroundings of Rose and Gellert Hills. The approach is based on the principle of hydrological system analysis (Engelen and Kloosterman 1996), which covers the evaluation of those historical situations when the influence of man on the hydrology of the region was still negligible. This was also amplified with recent observations of manifestations of flowing groundwater (e.g. caves, precipitates).

\section{Geologic and structural settings}

The Buda Thermal Karst System forms the NE extremity of the Transdanubian Central Range (TCR) (Fig. 1). The aquifer of the TCR is a several thousand meterthick Mesozoic carbonate sequence (Haas 1988). These Triassic carbonates, mostly dolomites (Main Dolomite and Mátyáshegy Formation), are the oldest known strata from the Buda Thermal Karst (Schafarzik and Vendl 1929; Wein 1977), that 
are separated from the overlying Eocene limestone by a long period of subaerial exposure that lasted from the Late Cretaceous to the Late Eocene. Related to this subaerial exposure event, a mature karst developed (Nádor 1994). Marine sedimentation was continuous from the Late Eocene to the Early Miocene. It began with the deposition of basal conglomerate beds, followed by shallow marine limestone (Szépvölgy Limestone), pelagic marl (Buda Marl), and clay (Kiscell and Tard Clay Formations) (Báldi 1983; Kázmér 1985; Nagymarosy et al. 1986). The total thickness of the Eocene-Oligocene strata is about $700 \mathrm{~m}$.

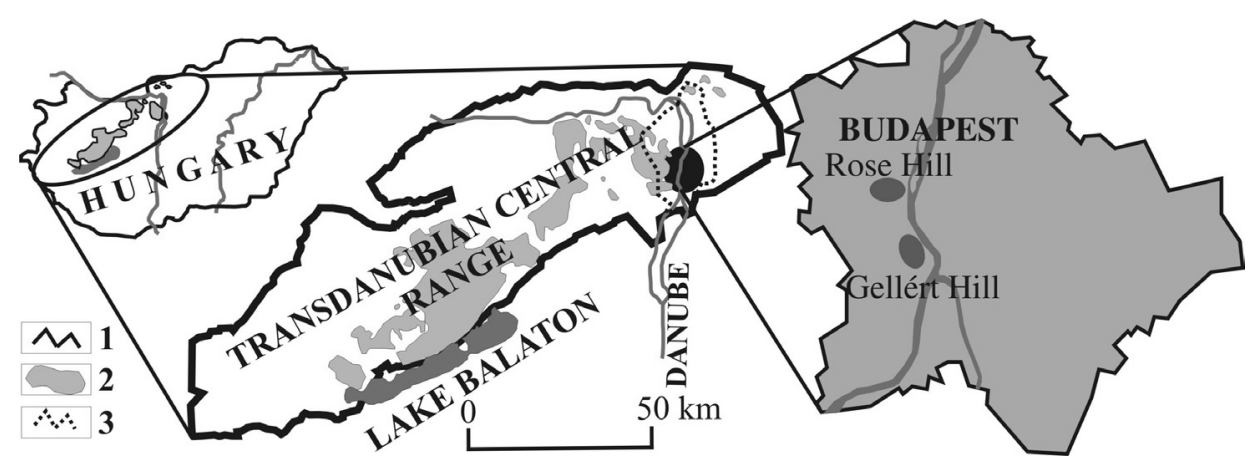

Fig. 1

Location of the Buda Thermal Karst in the Transdanubian Central Range and the Study Areas in Budapest: Rose Hill and Gellért Hill. 1. Subsurface boundary of Mesozoic carbonates; 2. Exposed Mesozoic carbonates; 3. Buda Thermal Karst

Post-volcanic fluids, possibly related to a Paleogene neutral volcanic body, penetrated into the Triassic-Eocene carbonates through faults (Nádor 1994). Along these faults and fractures, deep-seated fluids precipitated barite and calcite and caused silicification. In addition, leaching also occurred along these faults and fractures due to $\mathrm{CO}_{2}$-rich fluids as hypothesized by Müller (1989) and Nádor (1994). The gradual uplift of the area began in the Neogene, when the clay cover was eroded and the underlying Triassic-Eocene carbonates became exposed. The axial zone of the TCR has been characterized by a faster uplift $\left(0.41\right.$ mmyear $\left.^{-1}\right)$ than the marginal Buda Hills area (0.23-0.14 mmyear $^{-1}$ ) during the last $360 \mathrm{ky}$ of the Pleistocene (Ruszkiczay-Rüdiger et al. 2005). Related to the uplift, a regionalscale groundwater flow system has developed in the several thousands of meterthick carbonates of the TCR. This last stage of karstic evolution continues today.

According to Fodor et al. (1994) four tectonic phases can be distinguished in the Buda Thermal Karst area. During the Cretaceous, anticlines formed (with folds and smaller thrusts) and the rigid dolomite was fractured (Wein 1977) due to SE-NW compressional tectonism. From the Late Eocene to the Early Miocene, the area was intermittently influenced by large-scale strike-slip activity, WNW-ESE directed compression and perpendicular tension. The stress field changed in the Middle Miocene, and up to the Quaternary new N-S to NE-SW trending normal 
faults were formed by ESE-WNW extension. Pleistocene tectonic activity is characterized by N-S (NE-SW) extension and perpendicular compression.

Through the intensive tectonic evolution of the area, the fractures, faults and folds have a strong influence on the groundwater migration by flow channeling, and also control the dissolution and precipitation processes.

\section{Hydraulic regime}

The processes of the current hydrogeologic system are summarized in the conceptual models of Schafarzik (1928), Vendel and Kisházi (1964), Alföldi (1979, 1981, 1982), Kovács and Müller (1980) (Fig. 2).

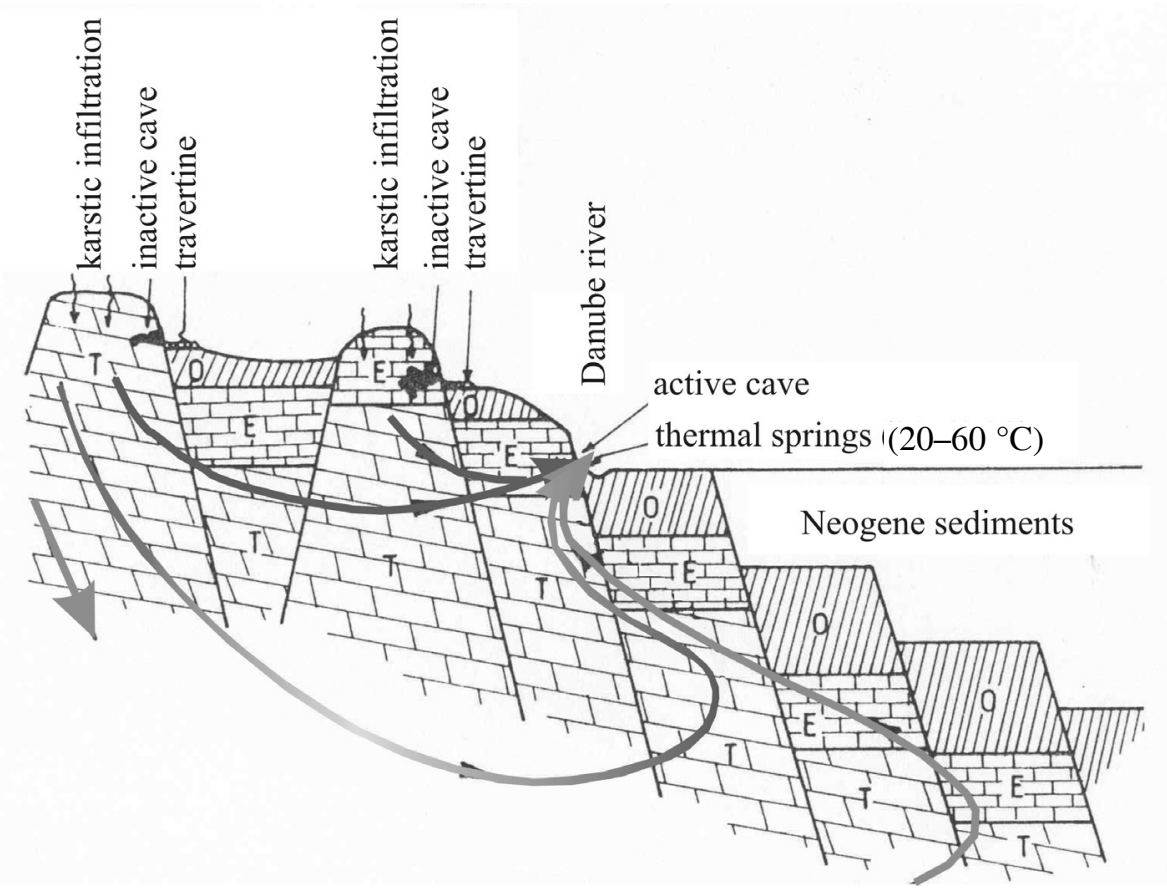

Fig. 2

Schematic cross-section of the Buda Thermal Karst (modified from Kovács and Müller 1980). T Triassic dolomite; E - Eocene limestone and Eocene-Oligocene marl; O - Oligocene clay

The karstic recharge area covers about 15\% of the entire TCR area (Lorberer 1986). This flow system is mainly gravitationally driven but also influenced by the geothermal heat (Alföldi 1982). The infiltration feeds a complex flow system with perennial discharge sites. Part of the main discharge zone at the northeastern extremity of TCR can be found in Budapest. Based on the modified model of Kovács and Müller (1980) the water follows a deep, regional-scale flow path, and 
returns to the surface as thermal water, generally along fault zones. The age of thermal waters in Budapest is $5000-16000$ years, based on ${ }^{14} \mathrm{C}$ isotope measurements (Deák 1978). The rest of the infiltrated water circulates via local or intermediate flow-systems and discharges as warm and lukewarm springs. The discharge zone, localized in Budapest, is separated by a step-faulted boundary from the subsided basin to the east (Pest) and the uplifted hilly range in the west (Buda). The course of the Danube follows this boundary and represents the base level of erosion.

Due to the mixing of ascending thermal waters, rich in dissolved solids, and descending meteoric waters, extensive cave systems have developed and are still developing. Several currently inactive and active underwater cave systems document this mixing process (Kovács and Müller 1980; Takács-Bolner and Kraus 1989; Leél-Őssy 1995; Leél-Őssy and Surányi 2003; Kalinovits 2006).

There are differences in hydrogeologic environment of the two test sites. The topographic elevation, as the main driving force for gravity driven flow, is $195 \mathrm{~m}$ asl in the case of Rose Hill. The Gellért Hill is of a height of $235 \mathrm{~m}$ asl. Rose Hill is built up of Eocene limestone and covered mainly by Eocene-Oligocene marl and a Pleistocene clayey detrital blanket. The Triassic dolomite here is deep-seated. Gellért Hill is built up of Triassic dolomite and is partly covered by marl, but at the nearest point to the Danube it shows up mainly as a bare karst surface (Fig. 3).

Fig. 3

A) Schematic stratigraphic column of the Gellért Hill area (modified after Korpás et al. 2002); B) Schematic stratigraphic column of the Rose Hill area (modified after Leél-Ôssy and Surányi 2003). 1. Main Dolomite Formation; 2. Mátyáshegy Limestone Formation; 3. Basal conglomerate and breccia; 4. Szépvölgy Limestone Formation; 5. Buda Marl Formation; 6. Tard Clay Formation; 7. Kiscell Clay Formation; 8. Törökbálint Sandstone Formation; 9. travertine; 10 . scree, sand, gravel, loess
A)

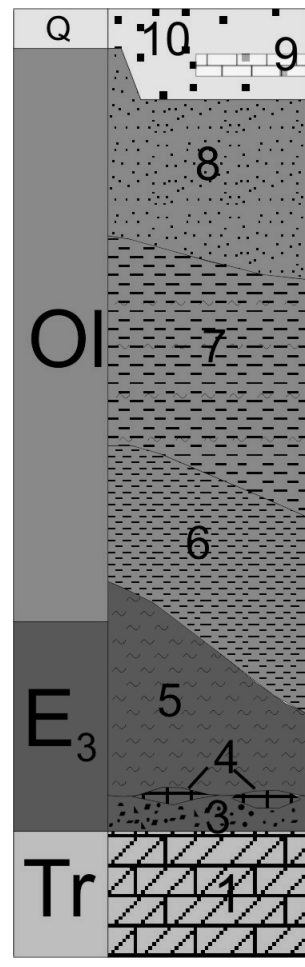

B)

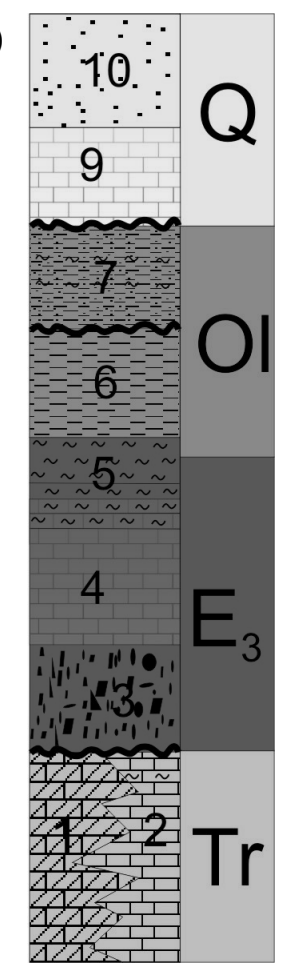




\section{Applied methods}

The approach of this study is principally based on the evaluation of historic hydrogeologic data, mainly from the first part of the 20th century when artificial influence on the hydrogeology of the region was still negligible. In this respect, archive data of the springs from the literature were used and evaluated. The main goals of the interpretation were to localize the position and characterize the temperature and chemical properties of former lukewarm $\left(20-30{ }^{\circ} \mathrm{C}\right)$, warm $\left(30-36.7{ }^{\circ} \mathrm{C}\right)$ and hot $\left(>36 .{ }^{\circ} \mathrm{C}\right)$ springs. Monographs (e.g. Mádai 1927; Horusitzky 1938; Papp 1942; Kunszt 1947; Schulhof 1957; Alföldi et al. 1968, etc.), papers, maps and reports were processed during the retrospective study. The most important comprehensive monographs were the works of Papp (1942) and Alföldi et al. (1968), which also summarize the data which were available at the time of compilation of their work.

For the geochemical characterization of the waters, first of all, the total dissolved solids (TDS) contents were used, because this parameter reflects the rock-water interaction along the flow path. Generally, the fresh infiltrated meteoric waters are characterized by low TDS content, while the thermal waters, moving along a regional flow path, have higher TDS (Tóth 1999). However, the urbanized environment can overwrite this general trend due to sewage breaks, salt spreading in winter, and other similar occurrences. The fluids were also classified using the hydrochemical facies concept of Back (1961).

The archive data evaluation was complemented by recent observations in caves and water chemistry measurements.

\section{Results}

\section{Characterization of discharge at the Rose Hill}

The collected archive data including temperature, discharge and chemical data, are summarized in Table 1, while Fig. 4 shows the original location of the springs. The triangles indicate the lukewarm-warm springs $\left(20-36.7^{\circ} \mathrm{C}\right)$, and the circles show the hot springs $\left(>36.7^{\circ} \mathrm{C}\right)$. At the foot of Rose Hill the hot springs $\left(>36.7^{\circ} \mathrm{C}\right)$ with high TDS $\left(800-1350 \mathrm{mgL}^{-1}\right)$ emerged nearest to the Danube. The warm and lukewarm springs $\left(20-36.7^{\circ} \mathrm{C}\right)$ with lower $\left(770-980 \mathrm{mgL}^{-1}\right)$ TDS content came to the surface between the hot springs and the foothills. There seems to be a border between them, which appears as a straight line. This line could correspond to a N-S (NNW-SSE) trending fault zone (Fodor, pers. comm. 2008). If we take a detailed look at the distribution of spring outlets, further lines indicate WNW-ESE and N-S (NNW-SSE) directions, which can also correspond to structural elements. These trends are also in alignment with the structural directions of the Rose Hill area, supporting a primary structural control on the distribution of springs. The hydrochemical facies of the lukewarm-warm and hot waters are $\mathrm{Ca}-\mathrm{Na}$ and $\mathrm{HCO}_{3}-\mathrm{Cl}-\mathrm{SO}_{4}$ type; however, the two temperature 
Characteristics of discharge at Rose and Gellért Hills, Budapest, Hungary 273

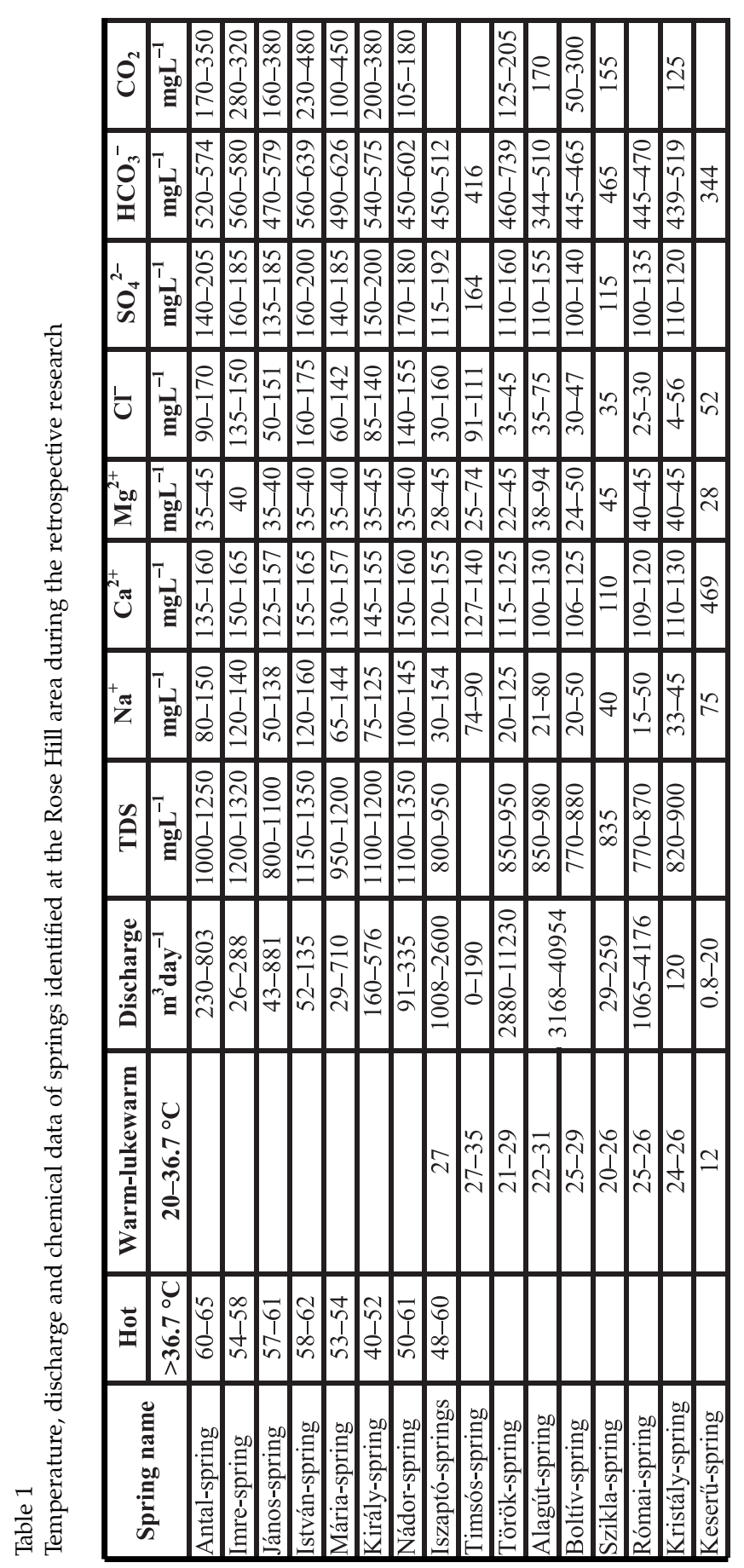

Central European Geology 51, 2008 
groups can be distinguished by their sodium and chloride contents. The hot springs contain higher concentrations of these ions. The hot springs also have a considerably higher dissolved $\mathrm{CO}_{2}$ (about 200-400 $\mathrm{mgL}^{-1}$ ) content.

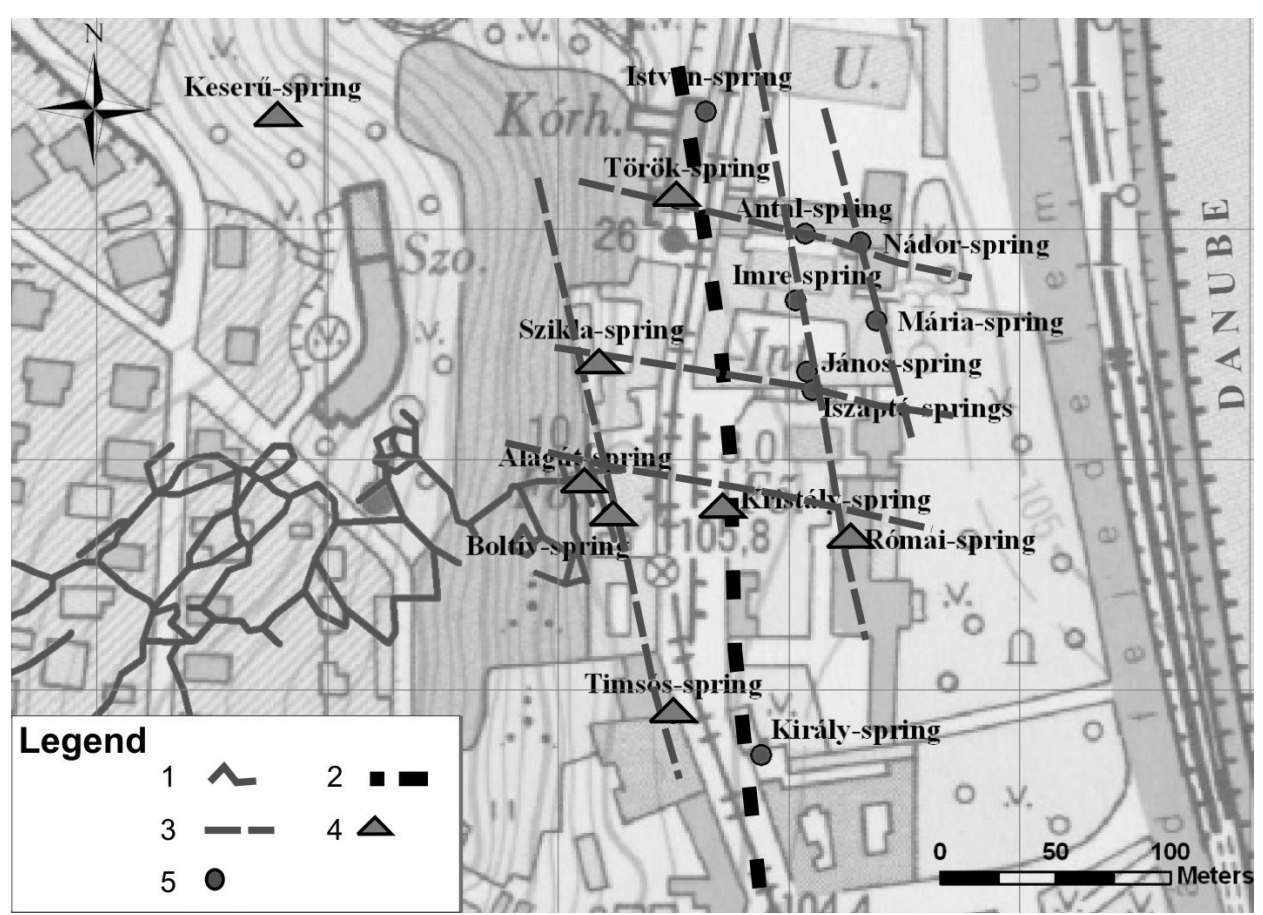

Fig. 4

Discharge features at Rose Hill. 1. traces of the underwater cave; 2. border between lukewarm-warm and hot springs; 3 . supposed structural elements; 4 . lukewarm and warm springs; 5 . hot springs

Behind the discharge zone of lukewarm-warm springs a large underwater cave system (Molnár János Cave) is situated (Fig. 4). The passages of this cave developed along fractures and/or the contact of the Eocene limestone and Eocene-Oligocene marl, in the same way as the other, now dry caves in the Rose Hill. The dimensions of this cave are extraordinary; the largest hall reaches the height of $80 \mathrm{~m}$ and the width of $24 \mathrm{~m}$. However, the passages closest to the entrance are narrow. It seems that they were not influenced as long by dissolution as the inner ones. $\mathrm{Ca}^{2+}$ and $\mathrm{HCO}_{3}{ }^{-}$contents of the water samples show an increase from the inner part $\left(108 \mathrm{mgL}^{-1} ; 416 \mathrm{mgL}^{-1}\right)$ of the cave toward the entrance $\left(120 \mathrm{mgL}^{-1} ; 465 \mathrm{mgL}^{-1}\right) . \mathrm{CO}_{2}$ concentrations show a similar trend. This suggests that dissolution (mixing corrosion) takes place near to the entrance of the cave. This is important from the point of view of the evolution of the system. The passages close to the entrance are probably the youngest parts of the 
cave and have been formed since the time when the gradual uplift reached today's discharge level. Their narrow dimensions support this idea. Temperature measurements in the cave showed that there is thermal stratification in the passages. Water temperature is $23-26^{\circ} \mathrm{C}$ near the water table and $\sim 19{ }^{\circ} \mathrm{C}$ at 25 to $35 \mathrm{~m}$ of depth. Thus, we assume that in the cave, presumably due to the high porosity and permeability, free convection exists. The lowest temperature in the cave $\left(19^{\circ} \mathrm{C}\right)$ is higher than the yearly average temperature $\left(10^{\circ} \mathrm{C}\right)$ as a result of the convective heat flow of the uprising waters.

In the outer part of the cave a red precipitation was found on the walls. These iron-manganese-hydroxide precipitates form when anoxic deep thermal waters (containing reduced $\mathrm{Fe}$ and $\mathrm{Mn}$ ions) mix with cold and oxygen-rich meteoric waters. These precipitates can thus serve as a useful tracer of mixing processes in thermal karst areas (Surbeck and Eisenlohr 1994; Gainon et al. 2007a, b). The distinct occurrence of these precipitations may indicate the place where the hydrothermal and meteoric waters meet.

\section{Characterization of discharge at the foot of Gellert Hill}

The location of the identified springs at the foot of Gellért Hill (Fig. 5) also illustrates that the location of the uprising waters corresponds to the main structural zone of Gellért Hill, which is a NW-SE normal fault zone (Korpás et al. 2002). Table 2 summarizes the collected archival data including temperature, discharge and chemical data. The temperature range of the springs was $33.5-43.5^{\circ} \mathrm{C}$, and their temporal and spatial variations are considered negligible. The TDS content of the waters varies between 1450 and $1700 \mathrm{mgL}^{-1}$, which is $350-400 \mathrm{mgL}^{-1}$ higher than the TDS content of the hot springs at Rose Hill. The chemical composition of these hot springs shows neither considerable temporal nor spatial variation. All water is of to the $\mathrm{Ca}-\mathrm{Na}$ and $\mathrm{Cl}-\mathrm{SO}_{4}-\mathrm{HCO}_{3}$ type. Almost all natural spring outlets form a small cave, or have at least enlarged orifices. Calcite and iron-manganese-hydroxide precipitates can be observed everywhere on and below the free water surfaces. The iron-manganese-hydroxide precipitates may suggest that mixing takes place; however, the distinct springs show similar chemical characteristics and temperature. Therefore, the mixing probably occurs inside the hill, and already mixed water emerges at surface.

A tunnel through Gellért Hill penetrated a dry cave (the so-called Aragonit Cave). This cave has a lenticular shape in which a clear horizon can be seen which consists of red deposits with calcite plates. These precipitates and the cave could be the paleo-analogue of the recently observed Gellért Hill spring caves. 


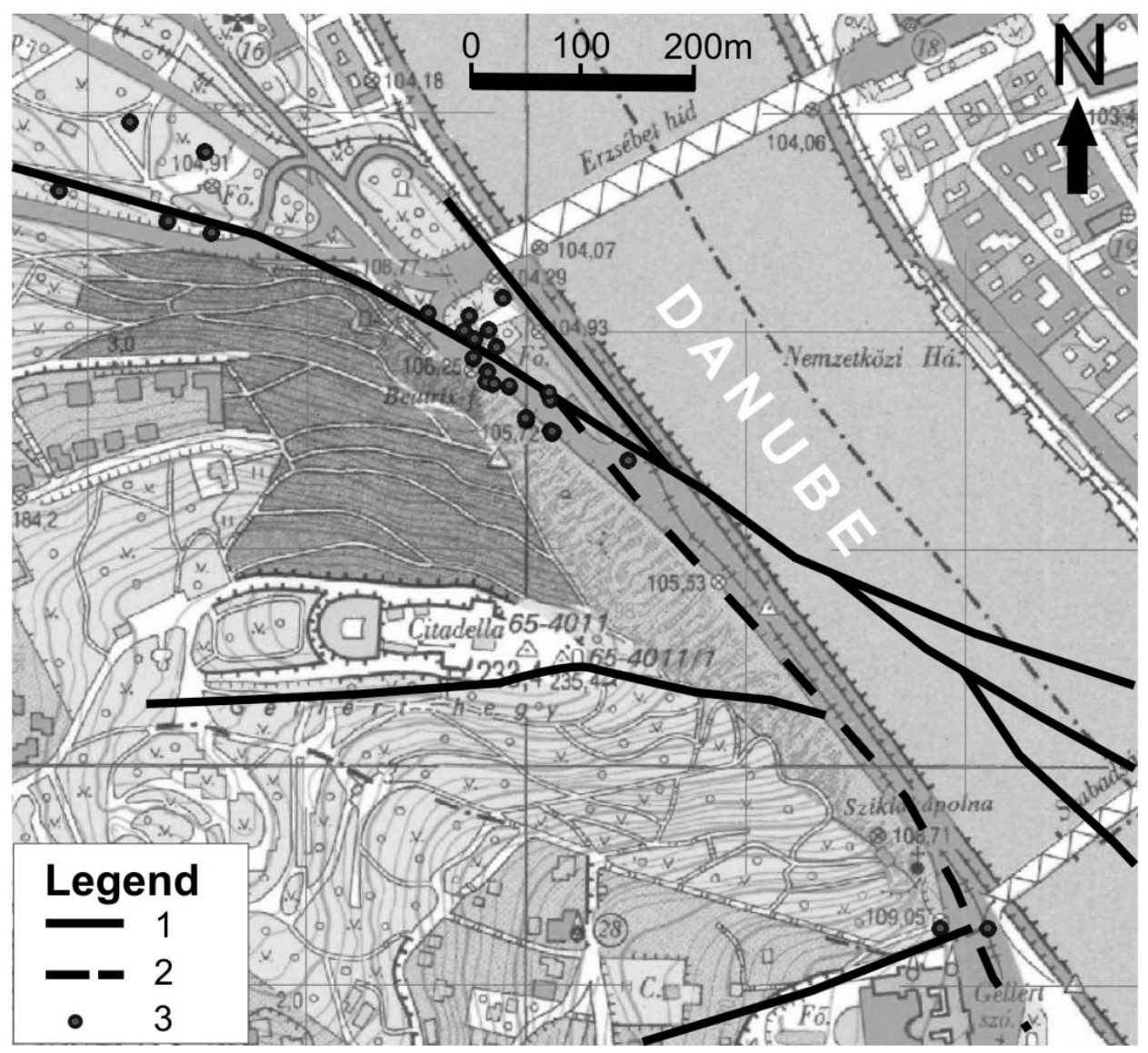

Fig. 5

Discharge features at Gellért Hill. 1. structural elements; 2. supposed structural elements; 3. hot springs

\section{Conclusion}

The main discharge characteristics of the two study areas can be summarized as follows:

The two study areas represent the nearest discharge areas to the Danube, i.e. the discharge of the local as well as the regional flow branches of the Buda Thermal Karst system. The forty-meter elevation difference, i.e. difference in driving force, results in a hydraulic gradient difference in the local flow systems. In addition, the Rose Hill area exposes Eocene carbonates with marl and detrital cover, which causes a buffered infiltration. In contrast Gellért Hill is a karst surface partly covered by marl; therefore the direct infiltration is more effective. Elevation and geologic differences together could mean more intensive flow, 
Characteristics of discharge at Rose and Gellért Hills, Budapest, Hungary 277

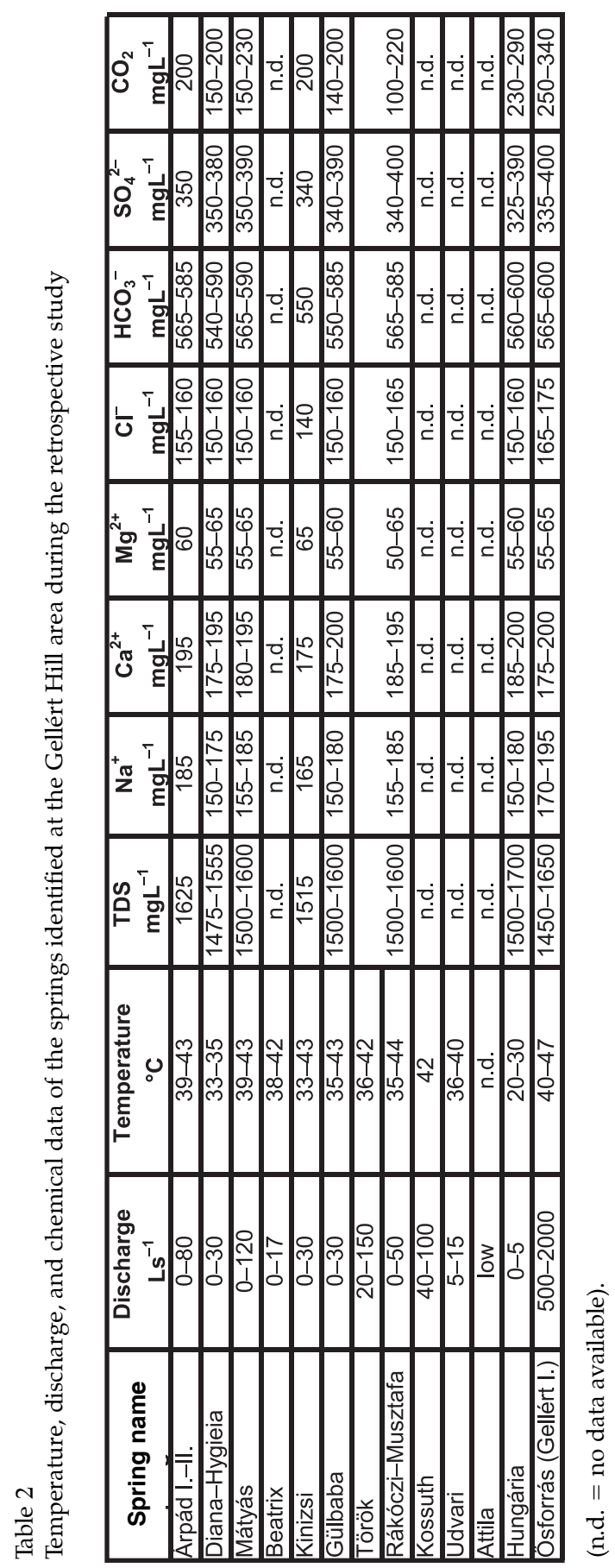


which means higher flux in the case of Gellért Hill. This may have an impact on mixing and dissolution/precipitation rates.

In both areas, the discharge is structurally controlled. At Rose Hill lukewarmwarm and hot springs arise at crossing faults with distinct temperatures and chemical compositions and are clearly separated by the boundary of flow systems. In contrast, the discharging springs at Gellért Hill provide a spatially (and temporally) uniform temperature and chemical composition, possibly due to the extensive microfracture system of the host dolomite that homogenizes the various fluids.

In both discharge areas caves can be found. The caves, however, developed in two distinct lithologies: in Triassic dolomite (Gellért Hill) and at the contact of Eocene limestone and Eocene-Oligocene marl (Rose Hill). Due to the differences in lithologies and geomechanical properties of the host rocks, cave morphologies in the Rose Hill and Gellért Hill areas are different. At Rose Hill, as a result of the bedding planes between limestone and marl and the multigenerational fault and fracture system, multiple-level complicated cave systems have developed along bedding planes and faults. In contrast, in the Gellért Hill area, due to the monomineralic host Triassic dolomite of uniform texture, lenticular, chamber-like, mostly isolated caves have formed that are also related to faults.

Iron-manganese-hydroxide precipitates can be found in both study areas. The occurrence of these precipitates may denote the mixing of anoxic deep hydrothermal waters and oxygen-rich meteoric waters. Behind the foot of Rose Hill, in the large underwater cave system, iron-manganese-hydroxide precipitates indicate an active mixing process between deep-seated hydrothermal and meteoric fluids. The distinct occurrence of these precipitations, together with the differences in the chemistry, may indicate the place where these waters mix, which is found in the outer part of the cave, close to the entrance. In the small spring caves of Gellért Hill iron-manganese-hydroxide precipitates also indicate mixing; however, the uniform chemistry and temperature of the issuing waters suggest that the location of the mixing process had probably already been "left behind", and the emerging spring waters are mixed ones.

Based on retrospective data analyses and recent field observations, conceptual models were established for the study areas (Fig. 6 and Fig. 7).

\section{Acknowledgements}

The research is part of the PhD study of A. Erôss and is funded by Shell International E\&P. This study is partly based on the MSc theses of I. Lieb (2004) on Rose Hill and R. Frész (2008) on Gellért Hill. The authors gratefully acknowledge the fruitful consultations with Prof. J. Tóth, Dr. N. Goldscheider, and Dr. H. Surbeck. 
BUDA

P E S T

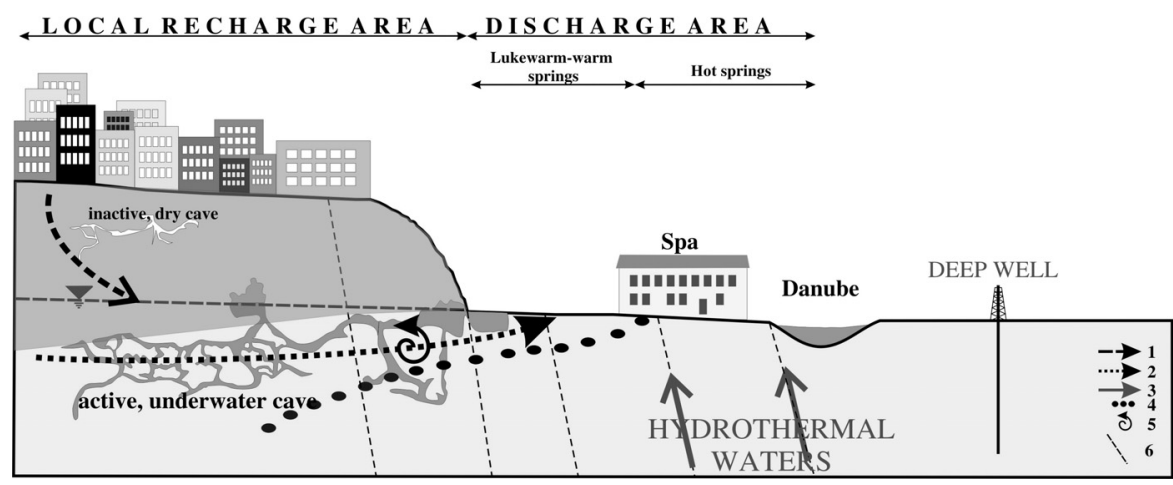

Fig. 6

Conceptual model of the discharge at Rose Hill. 1. local flow system; 2. intermediate flow system; 3. regional flow system; 4 . supposed boundary of local-intermediate and regional flow path: mixing zone; 5 . free convection; 6 . supposed structural elements

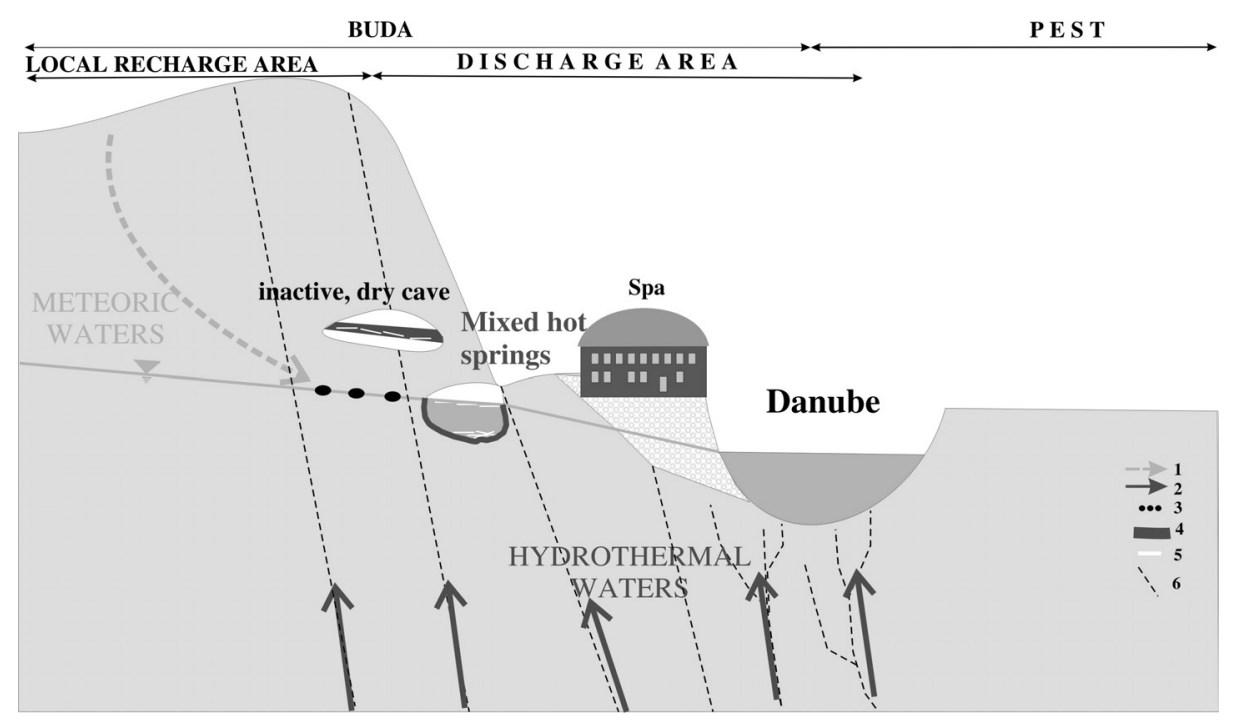

Fig. 7

Conceptual model of the discharge at Gellért Hill. 1 local flow system; 2. regional flow system; 3 . supposed boundary between local and regional flow paths: mixing zone; 4 . iron-manganesehydroxide precipitate; 5 . calcite rafts; 6 . supposed structural elements 


\section{References}

Alföldi, L. 1979: Budapesti hévizek (Thermal waters of Budapest). - VITUKI Közlemények, 20, pp. 1-102. (In Hungarian.)

Alföldi, L. 1981: A budapesti geotermikus áramlási rendszer modellje (Model of the geothermal flow system in Budapest). - Hidrológiai Közlöny, 61/9, pp. 397-403. (In Hungarian.)

Alföldi, L. 1982: A layered thermal-water twin flow system. - Journal of Hydrology, 56, pp. 99-105.

Alföldi, L., L. Bélteky, T. Böcker, J. Horváth, K. Korim, P. Liebe, R. Rémi 1968: Budapest Hévizei (Thermal waters of Budapest).- VITUKI, Budapest, 365 p. (In Hungarian.)

Back, W. 1961: Techniques for mapping of hydrochemical facies. - U. S. Geological Survey, Professional Paper, 424-D, pp. 380-382.

Back, W., J.S. Hermann, H. Paloc (Eds) 1992: Hydrogeology of selected karst regions. - International Associations of Hydrogeologists, Hanover, Germany, Verlag Heinz Heise GmbH and Co KG, 13, 493 p.

Báldi, T. 1983: Magyarországi oligocén és alsómiocén formációk (Oligocene and Lower Miocene Formations in Hungary). - Akadémiai Kiadó, Budapest, 293 p. (In Hungarian.)

Bedinger, M.S. 1967: An electrical analog study of the geometry of limestone solution. Groundwater, 5/1, pp. 24-28.

Deák, J. 1978: Environmental isotopes and water chemical studies for groundwater research in Hungary. - Isotope Hydrology, IAEA-SM-228/13, Vienna, IAEA, pp. 221-249.

Dublyansky, Y.V. 2000: Hydrothermal speleogenesis. Its settings and peculiar features. - In: Klimchouk, A.B., D.C. Ford, A.N. Palmer, W. Dreybrodt (Eds): Speleogenesis Evolution of Karst Aquifers. - National Speleological Society, Inc. Huntsville, Alabama, USA, pp. 298-303.

Engelen, G.B., F.H. Kloosterman 1996: Hydrological systems analysis: methods and applications. Kluwer Academic Publishers, Dordrecht, Boston, London, 152 p.

Fodor, L., Á. Magyari, A. Fogarasi, K. Palotás 1994: Tercier szerkezetfejlődés és késő paleogén üledékképződés a Budai-hegységben. A Budai-vonal új értelmezése (Tertiary tectonics and Late Paleogene sedimentation in the Buda Hills, Hungary. A new interpretation of the Buda line). Földtani Közlöny, 124/2, pp. 130-305. (In Hungarian.)

Gainon, F, N. Goldscheider, H. Surbeck 2007a: Conceptual model for the origin of high radon levels in spring waters - the example of the St. Placidus spring, Grisons, Swiss Alps. - Swiss Journal of Geosciences/Eclogae Geologicae Helvetiae, 100/2, pp. 251-262.

Gainon, F, H. Surbeck, F. Zwahlen 2007b: Natural radionuclides in groundwater as pollutants and as useful tracers. - Water Rock Interaction, 12, Kunming, China, Taylor and Francis, London, 1, pp 735-738.

Haas, J. 1988: Upper Triassic carbonate platform evolution in the Transdanubian Mid-Mountains. Acta Geologica Hungarica, 31/3-4, pp. 299-312.

Horusitzky, H. 1938: Budapest Dunajobbparti részének (Budának) hidrogeológiája (Hydrogeology of Buda). - Hidrológiai Közlöny, 18, pp. 1-404. (In Hungarian.)

Kalinovits, S. 2006: Molnár János-barlang új szakaszainak felfedezése (Discovery of the new passages of Molnár János Cave). - Karszt és Barlang 1995-1996, 3-8. (In Hungarian.)

Kázmér, M. 1985: Microfacies pattern of the Upper Eocene limestones at Budapest, Hungary. Annales Universitatis Scientiarum Budapestinensis, Sectio Geologica, 25, pp. 139-152.

Korpás, L., L. Fodor, Á. Magyari, Gy. Dénes, J. Oravecz 2002: A Gellért-hegy földtana, karszt- és szerkezetfejlődése (Geology, karst and structural evolution of Gellért Hill). - Karszt és Barlang, 1998-1999/ I-II, pp. 57-93. (In Hungarian.)

Kovács, J., P. Müller 1980: A budai-hegyek hévizes tevékenységének kialakulása és nyomai (Evolution and evidence of the thermal water activity in the Buda Hills). - Karszt és Barlang, II, pp. 93-98. (In Hungarian.)

Kunszt, J. 1947: A Rudas gyógyfürdő monográfiája. (Monograph of the Rudas Spa). - Mérnökök Nyomdája, Budapest, 224 p. (In Hungarian.) 
La Fleur, R.G. (Ed) 1984: Groundwater as a geomorphic agent. - Allen and Unwin Inc., Boston, USA, $390 \mathrm{p}$.

Leél-Őssy, Sz. 1995: A Rózsadomb és környékének különleges barlangjai (Particular caves of the Rózsadomb Area). - Földtani Közlöny, 125/3-4, pp. 363-432. (In Hungarian.)

Leél-Őssy, Sz., G. Surányi 2003: Peculiar hydrothermal caves in Budapest, Hungary. - Acta Geologica Hungarica, 46/4, pp. 407-436.

Lorberer, Á. 1986: A Dunántúli-középhegység karsztvízföldtani és vízgazdálkodási helyzetfelmérése és döntéselókészító értékelése (Assessment report about the karst hydrogeology and state of water management in the Transdanubian Central Range). I. - Summary Report (TSZ: 7611/1/62), VITUKI, Budapest, 130 p. (In Hungarian.)

Lorberer, Á. 2002: A budapesti termálkarszt állapotértékelése (State assessment of the Buda Thermal Karst). - VITUKI, Budapest, 45 p. (In Hungarian.)

Mádai, L. 1927: A Császárfürdő monográfiája (Monograph of the Császár Spa). - Pátria Irodalmi Vállalat és Nyomdai Részvénytársaság, Budapest, 92 p. (In Hungarian.)

Müller, P. 1989: Hydrothermal paleokarst of Hungary. - In: Bosák, P. et al. (Eds): Paleokarst - A systematic and regional review, Elsevier and Academia, Amsterdam and Praha, pp. 155-163.

Nádor, A. 1994: Paleokarstic features in Triassic-Eocene carbonates: Multiple unconformities of a 200 million year karst evolution, Buda Mountain, Hungary. - Zentralblatt für Geologie und Paläontologie, I/11-12, pp. 1317-1329.

Nagymarosy, A., T. Báldi, M. Horváth 1986: The Eocene-Oligocene boundary in Hungary. - In: Pomerol, C., I. Premoli-Silva (Eds): Terminal Eocene Events. Elsevier, Amsterdam, pp. 113-116

Papp, F. 1942: Budapest meleg gyógyforrásai (Thermal springs of Budapest). - A Budapesti Központi Gyógy- és Üdülőhelyi Bizottság Rheuma és Fürdőkutató Intézet kiadványa, Budapest, 252 p. (In Hungarian.)

Ruszkiczay-Rüdiger, Zs., L. Fodor, G. Bada, Sz. Leél-Őssy, E. Horváth, T.J. Dunai 2005: Quantification of Quaternary vertical movements in the central Pannonian Basin: A review of chronologic data along the Danube River, Hungary. - Tectonophysics, 410, pp. 157-172.

Schafarzik, F. 1928: Visszapillantás a budai hévforrások fejlődéstörténetére (The evolution of thermal springs in Buda). - Hidrológiai Közlöny, 1, pp. 9-14. (In Hungarian.)

Schafarzik, F, A. Vendl 1929: Geológiai kirándulások Budapest környékén (Geologic excursions in the surroundings of Budapest). - Stádium Sajtóvállalat Rt., Budapest, 343 p. (In Hungarian.)

Schulhof, Ö. (Ed.) 1957: Magyarország ásvány és gyógyvizei. (Mineral and spa waters of Hungary). - Akadémiai Kiadó, Budapest, 963 p. (In Hungarian.)

Surbeck, H., L. Eisenlohr 1994: Radon as a tracer in hydrogeology: a case study. - Environmental Geochemistry and Health, 16, pp. 91-100.

Takács-Bolner, K., S. Kraus 1989: A melegvizes eredetú barlangok kutatásának eredményei (Results of research into caves with thermal water origins). - Karszt és Barlang, I-II, pp. 61-66. (In Hungarian.)

Tóth, J. 1971: Groundwater discharge: A common generator of diverse geologic and morphologic phenomena. - International Association of Scientific Hydrology Bulletin, 16/1-3, pp. 7-24.

Tóth, J. 1984: The role of regional gravity flow in the chemical and thermal evolution of ground water. - In: Hitchon, B., E.I. Wallick (Eds): Proc First Canadian/American Conference on Hydrogeology, Practical Applications of Ground Water Geochemistry, Worthington, Ohio 1984, National Water Well Association and Alberta Research Council, pp. 3-39.

Tóth, J. 1999: Groundwater as a geologic agent: An overview of the causes, processes, and manifestations. - Hydrogeology Journal, 7/1, pp. 1-14.

Vendel, M., P. Kisházi 1964: Összefüggések melegforrások és karsztvizek között a DunántúliKözéphegységben megfigyelt viszonyok alapján (Relation between karstwaters and thermal springs with examples from the Transdanubian Central Range). - MTA Múszaki Tudományok Osztályának Közleményei, 32, pp. 393-417, 33, pp. 205-234. (In Hungarian.)

Wein, Gy. 1977: A Budai-hegység tektonikája (Tectonics of the Buda Hills). - MÁFI Alkalmi Kiadvány, 76 p. (In Hungarian.) 